\title{
Maintenance of karst biodiversity, with an emphasis upon Australian populations
}

\author{
Elery Hamilton-Smith \\ Chair, IUCN/WCPA Working Group on Cave and Karst Protection \\ P.O. Box 36, Carlton South, Victoria 3053, Australia \\ e-mail: elery@alexia.net.au
}

\begin{abstract}
Biospeleology - the study of cave-dwelling organisms - has long been recognised as making a major contribution to the understanding of both evolutionary and adaptive processes and community ecology. A focus on the broader concept of the karst environment as a whole leads to consideration of a much wider range of inter-dependent organisms, ranging from bacteria and other microbiota, through a wide range of terrestrial, freshwater and anchialine invertebrates, various vertebrates, and karst-dependent plant associations adapted to life on alkaline soils, often with cyclic aridity. This paper reviews the Australian biota, identifies the major threats to its continuing biodiversity and discusses the importance of, and potential strategies for, protection. It concludes by identifying major priorities for research and protective action.
\end{abstract}

\section{INTRODUCTION}

Although there has already been considerable world attention given to the conservation of underground fauna (e.g. Tercafs, 1992), this has been focussed on bats (e.g. Stebbins, 1988) and troglobitic invertebrates (e.g. Juberthie, 1995). The reports of both a symposium organised by the Karst Waters Institute (Sasowsky et al., 1997) and a recent IUCN/World Bank meeting (Vermeulen and Whitten 1999) are probably the only two such documents to deal with the total range of karst biota. A more detailed world review which includes a section on conservation, but which still tends to maintain a primary focus upon bats and invertebrates (Wilkens et al. 2000), is expected to appear in the coming year.

Within Australia there has been an increasing literature dealing with the conservation of karst biota, but again generally concentrated on troglobitic invertebrates or bats (e.g. Clarke, 1997; Duncan et al., 1999; Eberhard, Richardson and Swain, 1991; Eberhard and Spate, 1995; Eberhard and Hamilton-Smith, 2000; Humphreys, 2000; Poulter, 1991; Slaney and Weinstein, 1997).

\section{The Karst Context}

For present (and most other) purposes, it is important to think of karst as not just caves or landscape, but rather as '... a karst system, incorporating component landforms as well as life, energy, water, gases, soils and bedrock' (Eberhard, 1994: 8). Its integrity depends upon the preservation of the dynamic interaction between these various components, as abnormal perturbation in any one of them will have implications for all others. This dynamic/holistic approach to definition has now been widely adopted (e.g. Kiernan, 1995; Bozovic, 1997; Sket, 1997; Yuan, 1988)

Many rocks, including much unmetamorphosed limestone, have a degree of porosity to water which hydrologists refer to as primary or intergranular porosity. Karstified rocks are more much more porous, due to solutional processes, often commencing along joint or bedding planes. These first cavities or protocaves provide for secondary porosity, and a greatly increased water movement. In turn, caverns develop and where this has occurred the increased porosity provides for turbulent flow and often very rapid movement of immense bodies of water. However, this usually coexists with much slower flows through the stillexisting protocaves or other small voids [for a comprehensive review, see Gillieson (1996)].

From the biological perspective, it is vital to recognise that any karst system will have a spectrum of void dimensions, ranging from what Howarth (1983) has termed microcaverns. Howarth then uses the term mesocaverns for spaces ranging from $0.1 \mathrm{~cm}$ to, say, $20 \mathrm{~cm}$ which cannot generally be entered by humans and macrocaverns for spaces large enough for human entry or inspection. The differentiation between the first two of these levels of cavern is based in their hydrological properties and their relationship to flow patterns of groundwater (Ford and Williams, 1989). There is no equivalent conceptual boundary between mesocaverns and macrocaverns.

Much of the study of karst biota has focussed 
upon the macrocaverns, simply because these are the only caverns directly accessible to biologists. Those investigating aquatic species have often collected from springs, but may or may not have recognised the extent to which those springs are fed by mesocaverns. However, Howarth and many other workers have demonstrated the immense importance of the smaller voids as a habitat for invertebrates; much of the terrestrial cave fauna is in fact a mesocavernous fauna, adapted to live in these minute cavities with their relatively high humidity and high level of carbon dioxide. Further, many caverns have no direct entrance to the surface, and comprise vast networks of small tunnels near or below the watertable, and these provide the habitat for a complex aquatic fauna which has only recently even been recognised in Australia.

This distinction may well be vital in assessing any karst areas from a biological perspective. An outstanding example occurs at the Cape Range karst in north-western Australia, where proponents of quarrying had argued that the area in which they planned to quarry had no caves, and therefore quarrying at that site did not threaten the remarkable cavernous fauna of the region. Even a superficial examination showed that the rock was riddled with mesocaverns, and so provided for a potentially rich fauna indeed (Hamilton-Smith et al., 1998).

As already emphasised, most biospeleological work has focussed upon the subterranean fauna, particularly bats and troglobitic invertebrates. However, there is a wide range of other extremely important and often neglected karst-dependent species :

- microbiota: nanobia, fungi, bacteria, algae and other protozoa

- plants, including bryophytes and a wide range of vascular plants, each of which are adapted to and require an alkaline environment, and many of which are also adapted to survival in cyclically arid conditions

- invertebrates which depend upon the karst vegetation, or in some other way are limited to karst terrains

- vertebrates which depend upon specific vegetation associations, or utilise the karst terrain for shelter.

These are, of course included in regional studies from those parts of the world, e.g. Europe, North America, where immense regions are comprised of calcareous rocks, but the influence of the karst environment may well betaken for granted and not subjected to systematic analysis.

\section{Importance of karst biota}

The need for preservation of obscure, or often even large and familiar, species of plants and animals is sometimes questioned. However, the intrinsic right of all species to survival is now being much more widely accepted as a basic principle in environmental management. One Australian speleologist (Poulter, 1991) has attracted some attention to this issue by using the phrase 'Cave rights for Troglobites!' The central discussion of this paper is therefore not so much on why we should ensure the survival of species, but how this might be best implemented.

However, it is useful to also note some of the anthropocentric arguments which might usefully support efforts in protection. Karst biota provides a natural laboratory of great richness which can support research into evolutionary processes, environmental adaptation, geoclimatic history and population dynamics to name but a few areas. Certainly the remarkable discoveries of diverse cave-adapted communities in northern Queensland (Howarth and Stone, 1990) and from Cape Range to the Kimberley in Western Australia (Eberhard and Humphreys, 2000) have made a significant contribution to the understanding of evolutionary processes and Australasian geoclimatic history. The contribution of maintaining bio-diversity within the overall gene reservoir has been argued extensively in other contexts. Cave microbiota hold specific promise in the very practical and economically valuable pharmaceutical industry.

Then human interest in many karst species watching the spectacle of bat flights, the occurrence of karst-dependent and often very beautiful plant species, the intriguing and often beautiful character of many cave invertebrates and doubtless many other possibilities - all give a more human dimension to their importance. It has been argued (Danielopol, 1998) that that more attention should be paid to the aesthetics of cave biota through its relationship with art - an idea which seems to resonate with the recent discoveries of cave bear skulls arranged in aesthetically pleasing patterns by our forefathers of 75,000 years ago (Lascu, 1996), and the further evidence from even very early rock art.

\section{The pattern of Australian karst biota}

Anything like a comprehensive review does not yet exist. Probably the broadest review is contained in a paper by Eberhard and Humphreys (2000).

The micro-biota include, as in any community, an immense diversity of bacteria, fungi, algae, protozoans and other forms. There has been an interest in cave microbiota since the pioneering work of Dudich in the 1930s and this is reviewed in the Encyclopaedia Biospeologica (Juberthie and Decu, 1994). Chapman (1993) provided a very accessible discussion of what was then known about the role of microbiota in the ecology of cave communities. 
However, recent discoveries in other continents have generated immense interest, and a new generation of research (e.g. Northup et al., 1997a). A striking example which demonstrates the extent of current interest amongst karst scholars in the United States can be seen by reviewing the abstracts of papers presented at the 1998 convention of the National Speleological Society (1998).

Regrettably, we still know very little about this component of the Australian karst biota. Managers have paid attention to lampenflora in tourist caves, and developed techniques for prevention or control of its development (e.g. Johnson, 1979). Bacterial production of carbon dioxide has been recognised, and at Bungonia Caves is associated with precipitation of iron minerals (James, 1994a, 1994b). The role of algae in the deposition of phototropic speleothems is widely recognised (Spate, 1997), but has only been studied in the stromatolitic speleothems of Jenolan and some other New South Wales areas (Cox et al., 1989; James et al., 1994). Sulphur-metabolising bacteria have been recognised at Bungonia Caves (James, 1994b) and in Weebubbie Cave on the Nullarbor Plain (James and Rogers, 1996). It is now clear that microbiota play a much greater role than previously thought in the food web of subterranean communities, in speleothem development and in other geomineralogical processes within karst, including speleogenesis.

Most biological investigation in karst has focussed upon the considerable spectrum of terrestrial invertebrates, ranging from the interstitial species of soils and micro-caverns to the well-known and widely studied troglobites and troglophiles. These pose a special problem in protection because of the remarkable degree of adaptive radiation and endemism - in the Australasian region it is not unusual for species to be confined to a single cave or single karst outcrop. The Australian fauna has been described within the context of regional biogeography by Eberhard and Hamilton-Smith (2000) and more broadly by Eberhard and Humphreys (2000).

The aquatic environment occurs in a range of forms. Streams and rivers are important in many karst provinces, especially in the impounded karsts (or Karst Barré) of the Eastern highlands. Jennings (1985) draws special attention to this phenomenon, where relatively small areas of karst are completely surrounded by impervious rocks, and so exhibit various distinctive characteristics. Widespread and often diffuse groundwater aquifers are well-known in extensive karsts. Island karsts have a distinctive pattern of water movement, and may demand special consideration. In many island and coastal karsts, the anchialine zone, where fresh and saltwater mix, provides for a distinctive faunal community, as, for example, in Cape Range in
Western Australia, and many Pacific and Caribbean countries. It is only in recent years that the importance of these various habitats has been recognised in Australia, and this is currently the leading edge of Australian biospeleological research.

Trogloxenes, particularly birds and bats, have attracted an immense amount of study, and we know that the survival of many species is dependent upon the availability of appropriate cave environments. It is also clear that the trogloxenes provide the greater mass of food inputs to many cave ecosystems. Only one Australian bird, the swiftlet Aerodramus spodiopygius (Forster, 1845), can be considered truly be cave-dependent (Pecotich, 1980, 1982; Smyth et al., 1980) but many bats are normally cave-dwelling (Churchill, 1998; Duncan et al., 1999). In turn, the guano of cave-dwelling swiftlets and bats provide food for distinctive invertebrate populations.

The surface vegetation of karst is often distinctive and supports a wide range of karst-endemic species. Only the eastern European countries have a long-standing recognition of the special features of karst vegetation and a long record of research. Again, there is a high degree of localised endemism, due at least in part to the diversity of microclimate in karst areas.

At least in Australia, localised endemism is well developed in the tropics but appears to be absent or generally of minor significance in temperate areas. However, this may well reflect the extremely limited attention to this issue. In Central Queensland, the semi-evergreen vine thicket forest (Webb and Tracey, 1970) is a relict of the IndoMalaysian flora which was at one time far more widespread in Australia and is now only found on the Central Queensland limestones. It is characterised by tolerance of seasonal aridity and lack of resistance to wildfire, which has led to stands elsewhere in Northern Australia being replaced by Eucalyptus forest. At Chillagoe one finds both semi-evergreen and deciduous vine thicket forests along with other associations on the non-karst land units (Godwin, 1983). Again, these forests survive because the karst surface provides protection from wildfire. The composition of the flora is shaped by the alkalinity of the soils, semiarid climate, and for the larger trees (particularly the figs), access to ground-water. The deciduous forest is not only visually striking, but is the only extensive deciduous association in Australia.

The vegetation of Cape Range is remarkably diverse, with both tropical and temperate species, many of which are at the northern or southern limits of their range, a complex patterning and inter-relationship of four different plant communities, and a number of disjunct occurrences (Keighery and Gibson, 1993). Similarly in the East 
Kimberley one finds an "open savanna" vine thicket flora (McKenzie, personal communication), the study of which is only in its early stages. This association provides the habitat for a striking example of local endemism amongst camaenid land snail species and genera, with some species being restricted to a single hill. The 27 land snail species recognised have a geographic range averaging one square $\mathrm{km}$ (Solem, 1988; Woodruff and Solem, 1990). Although Solem described this as '... perhaps the greatest concentration of short range restricted endemic species found anywhere in the world. . $\therefore$, it must be pointed out that a number of comparable occurrences have now been identified in the rain forests of south-east Asia (Vermeulen and Whitten 1999, Vermeulen, personal communication)

In more temperate areas, there are few karstpreferring species of vascular plants, but many bryophytes do appear to favour karst over other environments. Studies by Downing (1992, 1997, 1998), Downing and Selkirk (1993), Downing et al., (1991, 1995, 1997) show that in limestone areas, bryophytes are both more diverse and more numerous on limestone than on adjoining rocks. Species found on limestone appear to be responding to the alkaline conditions, the relative surface aridity of karst and the diversity of micro-habitats. Many species are also found in arid areas, particularly on alkaline soils. Not surprisingly, this is not dissimilar in character to the patterns of vascular plant distribution on many tropical karsts.

This distinctive vegetation together with the often highly dissected terrain of karst leads in turn to an especially attractive surface environment for specific species of invertebrates, reptiles, birds and mammals. At least some species may be wholly confined to karst regions, but again, there is a great lack of knowledge.

\section{Threats to the survival of karst biota}

Many of the threats to karst biota are the largescale events which threaten the very integrity or even survival of the karst itself. These have already been reviewed in Watson et al. (1997) and so they are summarised here without extended discussion :

$\begin{array}{ll}\text { Total Destruction } & \text { as a result of mining, quarry- } \\ \text { of Karst } & \text { ing, submersion beneath } \\ & \text { water storages }\end{array}$

Major land or hydrological disturbance
Pollution

Sewage and domestic drainage, farm or industrial wastes, hydrocarbons from fuel spillage, microbial pollution.

Human Entry to
caves or other
utilisation

military use, religious observances and monuments, sanitoria, burial, manufacturing, dwelling sites, farming, wine-making, smuggling, research, tourism, concert auditoria, recreation and tourism

This listing does not make any judgement about the desirability and acceptability of any specific practice; it simply points to a range of phenomena which will have a threatening impact of greater or lesser degree. Many of the phenomena mentioned are of long-standing practice, are culturally approved, and often extremely desirable in their own right. But all demand due assessment when a new activity is contemplated or initiated, and continuing re-assessment through their continuing existence.

Threats of specific significance to the biota of karst include all of the above, many of which may have a both direct and indirect impacts. For instance, clearing of vegetation obviously destroys the flora, some of which will recover given the opportunity for re-vegetation, but other elements of the flora may never return. But the destruction of vegetation also impacts upon soil quality and the biological dynamics of the soil. This in turn changes the water regime within underlying caves and impacts directly upon microflora. The whole food chain of the fauna thus changes, and again species may well be destroyed. Generally, studies of karst biota have only taken place long after disturbance of the surface environments, and so many of the communities upon which we have based our understandings have already been very significantly modified and may well have suffered impoverishment. Thus, we must recognise that there may well be very special opportunities for research and protection in undisturbed areas.

Changes in water levels, either drying out of caves or flooding, quarrying, changes in land use and pollution are all likely to result in loss of fauna. These activities may well take place at a considerable distance from the site which is impacted, and thus may destroy a population in an otherwise protected area.

Examples in Australia include:

- extinction of the glow worm population at Flowery Gully, Tasmania as a result of land clearing and reduced runoff (Lichon, 1993)

- loss of fauna, particularly Hydrobiid snails, from silting of passages in Exit Cave, within the Tasmanian World Heritage Area, as a result of 
quarrying outside of the WHA boundary (Eberhard, 1997)

- loss of virtually all fauna from Bradley Chesterman Cave as a result of the same quarrying operation along with eutrophication and toxic pollution (Eberhard, 1997)

- flooding of Texas Caves in Queensland killed the total karst community, including an endemic silverfish (Archer, 1978; Smith and Shipp, 1978)

- disappearance of a large population of Bentwinged bats (Miniopterus) from Mt Widderin Cave, Skipton, Victoria as a result of land clearing (Simpson and Smith, 1964), and a resulting decline in the associated invertebrate community (Hamilton-Smith, 1968), followed by virtual extinction of invertebrates as a result of excessive trampling of the floor.

Even when an area is placed under protection, the development activities and constructions which provide for visitors and a range of other management initiatives can have a drastic impact. The construction of roadways, car-parks and buildings, if not undertaken with wisdom and sensitivity, can have remarkably destructive impacts on the karst environment. In brief, declaration of protected areas is not enough in itself - it must be accompanied by environmentally sensitive management.

Pollution, whether by soluble or liquid substances or by increased sedimentation, is likely to have severe impacts, often over very large areas and Juberthie (1995: 36-39) provides an excellent review of this problem in relation to troglobitic faunas. However, there is some evidence that recovery from water-borne pollution may occur relatively quickly as new populations enter the system from unpolluted watersheds (Lewis, 1996). One of the more insidious and potentially disastrous forms of pollution is the eutrophication of major aquifers by the use of agricultural fertilisers. In two regions of Australia where stromatolites are living in karst lakes or cenotes, this has resulted in the growth of dense mats of invasive species of algae and other water plants and in turn this reduces the penetration of sunlight to the point where the algae responsible for stromatolite development may well be killed (MacNamara, 1992; Thurgate, 1995).

Most recently, an extremely rich and diverse guanophile community in the Bat Cave, Naracoorte, South Australia (Hamilton-Smith, 1972) has been almost totally eliminated. This event is still under investigation, but it appears to the result of an insecticide which has been proven to occur in the upper layer of guano deposits in the cave. It is thus part of the changes in environmental conditions due to changes in land use with increasing agriculture and new technology in insect eradication.

Another common source of pollution results from the development of pathways and other structures for tourist access to caves; potentially dangerous pollutants are often introduced to the cave. These include copper from discarded waste left by electrician, zinc and cadmium from galvanised metals and hydrocarbon spillage. A recent review of this problem at least raises a warning to those responsible, and develops a series of proposals for improved practice (Spate et al., 1998).

Human entry to caves may have drastic impacts. Part of the problem is that many people see speleothems as the karst resource of most importance and totally ignore the value of the cave floor. As a generalisation, in spite of the very real aesthetic value of speleothems, they are both incredibly abundant and of limited other value. Floors, on the other hand, are often an incredible library of natural records of the past - layered sediments, pollens, sub-fossils from many phyla of the animal kingdom, and human or proto-human bones or artefacts. From the perspective of this paper, they are one of the more important biotopes, often the key habitat for both microbiota and a diversity of invertebrates.

In caves which have been developed for tourism, pathways have usually been laid on the cave floor with no regard to what may be destroyed in the process. However, with proper path construction, the environment may well provide more effectively for continuing survival of biota than might otherwise be the case. As noted above, at $\mathrm{Mt}$ Widderin a remarkable relict community of guanophilic invertebrates which had survived for 100 years after the departure of the bats on which they had depended for food (Hamilton-Smith, 1968) was wiped out in a couple of years by indiscriminate trampling of the cave floor. A simple elevated pathway system would have prevented this catastrophe.

Turning to threats which are specific to biota, two problems seem to be pre-eminent. The first, regrettably, is over-zealous or poorly planned research and collecting (Slaney and Weinstein, 1997). Many of us have encountered this problem, and it is alarming that often those responsible are scientists. There is probably a much smaller problem with collecting for commercial purposes although in Europe, the market for troglobitic species, especially beetles, has been a significant problem, while in Thailand, the survival of Kitti's bat (Craseonycteris thonglongyai Hill) was severely threatened until the government stepped in to control collection and trafficking, apparently with reasonable success.

The second is the problem of invasive species. The ubiquitous cockroaches Periplaneta americana L. (Yussof, 1997: 7-8, 29-30) and P. australasiae F. (Price and Steiner, 1999) have invaded the Batu Caves of Malaysia in enormous numbers and both 
have been recorded from other cave sites in Malaysia and Thailand. Regrettably, this invasion was well established by the time it was properly recognised, but seems to have been associated with the opening of the cave for visitors in 1974, and may have been carried in with building materials or even on the feet of visitors. It has been suggested that this invasion may well be largely responsible for the major decline in populations of both the Malaysian cave cockroach, Pycnoscelus striatus Kirby, and the remarkable Liphistius batuensis Abraham spiders for which this cave was famous.

At another level, Downing (1997, 1998, also Downing et al., 1997) has described the way in which invasive species have led to a decline in the endemic species of bryophytic flora on karst. More obviously, the vine thicket forests of Northern Australia have been severely damaged by the invasion of both Lantana and Rubber Vine.

There are doubtless hundreds of other examples and many may be unrecognised because the invasion occurred prior to relevant biological research. As a possible Australian example, the dominant ubiquitous scavenger beetle Alphitobius diaperinus Panz. in Bat Cleft Cave at Mt. Etna, Queensland, may be part of the original fauna, but is more likely to have arrived in the cave since Western settlement (Hamilton-Smith, 1970). There is certainly some invasion by microbiota, but again, there is too little research to detail this in Australia.

\section{Ensuring Protection}

There is a hierarchy of possible protection strategies which may be utilised (Eberhard and Hamilton-Smith, 2000).

\section{Legislative protection of species}

While many countries have in fact enacted species protection of a number of vertebrates and plants, and this has been utilised in the protection of cave fauna in at least both Slovenia (since 1922) and Croatia, Tasmania and Western Australia are the only state of Australia where cavernicolous invertebrates have been proclaimed as protected species, one of which is also coverd by Commonwealth legislation. However, the effectiveness of this approach has been questioned on a number of grounds: species must be individually identified in the legislation and this may pose taxonomic difficulties while many species of cavernicoles are undescribed and so cannot be listed; enforcement is virtually impossible; and species protection cannot be invoked to prevent the destruction of habitat. There are now moves to develop legislative protection of specific ecological communities, and if able to be implemented successfully, this will be an effective response to some of the difficulties inherent in species protection, and may offer excellent possibilities in relation to karst communities. Several subterranean communities have been declared protected in Western Australia, including troglobitic, stygal and root mat ecosystems.

\section{Recovery planning for threatened species}

The development of systematic recovery plans for species or groups of species is being developed in some countries. Although the effectiveness of this is often constrained by lack of research and the very complexity of ecological communities, there may well be occasions on which it might be very usefully invoked. The Bat Action plan (Duncan et al., 1999) is an excellent and relevant Australian example. The rehabilitation of the Ida Bay quarry site in Tasmania also provides a specific example of planned action to restore a cave community (see below).

\section{Protection of Specific Habitat Areas}

In itself, this group of strategies provides a considerable hierarchy of approaches. At the smallest level, it includes actions such as:

- track marking in caves to prevent trampling,

- development and voluntary observance of minimum impact codes for cavers or researchers. This is an important initiative which targets populations of cavers and researchers. An Australian example is provided in Watson et al. (1997) while many other fine examples have been developed, certainly including those of the United Kingdom and Switzerland.

- closure of caves or karst areas (often at specific seasons for the special purpose of protecting crucial bat sites). One such example, voluntarily instituted by cavers, resulted in the recovery of a bat population after a 20-year absence (Hamilton-Smith, 1991).

- finding means to minimise, control or eliminate invasive species

One of the dilemmas which we currently face is that having recognised the importance of microbiota, we lack the detailed knowledge to develop sound protection programs. But both invasive species and pollution represent clear threats, and the latter must be more broadly defined than is often the case. Invasive species are also a significant threat. Pollution includes any importation of organic matter, even including the skin flakes, hair and lint left behind by any human entry. It also includes any materials, e.g. clothes which are not freshly laundered, or dirty boots, which may serve to carry invasive species of microbiota. Northup et al. (1997b) have developed a 
series of practical guidelines for use by cavers and researchers. These are unlikely to be widely observed in many situations - and some caves have already been so impacted that any damage has already been done. However, they may be of great importance in entering and assessing new and previously uninvestigated cave systems. There is a further major threat in alteration of air movements in any previously closed or severely constricted cave.

However, area protection may also be developed on a broad-scale level, and the proper location of limestone quarries is an excellent example of this. Quarrying is one of the major threats to the integrity of karst in many countries, and often demonstrates a virtually irreconcilable conflict of interest. Major disputes have occurred in Australia at Mt Etna (Queensland), Yessabah, Colong, Bungonia and Wombeyan (New South Wales), Sellick's Hill (in South Australia) and Ida Bay (Tasmania). But five of these Australian examples are no longer being actively quarried, and three are receiving extensive and thorough rehabilitation. Steps are now under way to develop a greater recognition of conservation values and to negotiate both cooperative planning on extraction and the use of new technology which will ameliorate impacts upon the biota.

\section{Rehabilitation and Restoration}

Which brings us to the growing importance of rehabilitation and restoration. Both tourism managers and speleologists have been involved in aesthetic restoration of caves, often with conspicuous success, and in turn this may well restore cave habitats.

More importantly, there are now outstanding examples of restoration of total karst habitat, including:

- Waitomo Cave, New Zealand, where the famous glow-worm population was seriously threatened by degradation of the wetland habitats which produced the rich population of Diptera upon they depended for food,

- The Horse Cave and Hidden River system in Kentucky, U.S.A., where cessation of the practice of using the cave for sewage and waste disposal had led to an extensive recovery of the faunal community (Lewis, 1966),

- Ida Bay Caves, in the Tasmanian World Heritage Area, where cessation of quarrying and rehabilitation of the former quarry led to a remarkably rapid recovery of biotic communities. The decision was made to not utilise the artificial fertilisers demanded by forest ecologists as their use would have had negative impacts on the troglobitic and other underground biota. This project demonstrates in various ways the importance of adapting rehabilitation technology to a research-based understanding of the site concerned, rather than seeking any set of rigorous and universalised procedures (Eberhard, 1997; Houshold, 1997; Gillieson, 1995).

\section{Declaration of National Parks and other Protected Areas}

This is clearly the option which has the best potential to protect total environmental systems, such a karst province. However, several warnings must be noted:

- It is all too common for a government to declare parks, encourage (even just by making the decision) the public to visit them, yet not provide adequate resources for safeguarding of park values. The result may well be an increase in degradation of the environment. In other words, declaration is not enough: it must be accompanied by adequate resources for management and protection of park values. There are often major issues here in the lack of expertise on issues in karst management, and consequently a very real need for development of professional education for karst managers.

- The boundaries of karst drainage systems often do not co-incide with surface drainage systems. Unless the total watershed is included within park boundaries, this may lead to significant changes in the water regime within the park as a result of off-park actions (Neale, 1985). Waitomo (New Zealand) provides a welldocumented example, where the karst system was seriously threatened by increased sedimentation. However, this also demonstrates that where it is not realistic to include the total watershed within park boundaries, a problem may be solved by negotiation with neighbouring landholders and/or using available planning ordinances (Simmons and Lohrey, 1985).

On the more positive side, not only has there been an immense increase world-wide in the total area under some form of permanent resource protection, but there has been a steady increase in global expenditure on resource protection and a rapidly growing body of research and knowledge.

International agencies have provided a valuable resource in supporting this development, while international treaties have provided for World Heritage Recognition, usually with substantial strengthening of management. The recent recognition, initially in Australia (Australian Nature Conservation Agency, 1996), of some major karst aquifers as wetlands under the Ramsar Convention provides a further tool for protection and this is currently under examination in Eastern Europe also. 


\section{Public Education}

The importance of public education can never be neglected. The development of more effective karst protection, in the long run, depends upon the legitimisation of governmental action by the public as a whole. This must encompass a spectrum from the inclusion of karst understandings in science education, the education of park managers, cavers , tourism operations and others actively involved in karst utilisation, land owners, to wider public education through interpretation at parks, journalism, electronic media and popular books for all ages.

\section{Some Key Issues}

It is clear from discussion throughout this paper that many aspects of the Australian karst environment have not been adequately investigated. In particular, all too little is known of the surface flora and fauna. We have come to realise that if we are to develop a satisfactory understanding of the surface ecology of karst that we must recognise the extent to which there is often a mosaic of micro-habitats, each with their own microclimate, soils and, biotic community. Thus at Jenolan Caves it has proved necessary to develop a special series of maps developed in order to provide for recording of this data (Thurgate and Gillieson, 1999). Similarly, we have already referred to the findings of Keighery and Gibson (1993) on the Cape Range flora. In brief, overall generalisations are not enough - we need to understand the complex nature of, and interrelationships between, the various microhabitats.

There are also very few cave communities where we have developed an understanding of the ecology. Again, although it is vital to accurately determine species, we also need to understand the various community structures, and where a number of discrete communities occur in one cave system, the relationships between them.

Turning to conservation, it now appears that many cave communities may not be as vulnerable as we once thought. If, as discussed above, the primary habitat of many troglobitic invertebrates is in the mesocaverns, then these are not likely to be significantly impacted by human entry and impact in the macrocaverns. Lewis (1996) has certainly invoked this as one source of the recovery populations in the Hidden River System in Kentucky. But we still need much better public understanding, more rigorous controls over both levels and pollution of karst aquifers and much more adequately karst-sensitive environmental impact assessments.

\section{Conclusion}

This paper provides an all too brief overview of some key issues in karst protection. Australia is fortunate in that some of us commenced working actively to promote better protection and management of karst over 40 years ago - it has been a long road, so we have both a lot of experience and a lot of mistakes from which we have learned more. We still have a long way to continue travelling along that road, even turning back at regular intervals to revisit parts already travelled.

Regrettably, one of the things we have learned is that resource protection is a continuing struggle with human greed and global industrialisation (Bonyhardy, 1993: 145-146). Although the last 25 years have seen immense advances in protection, we have also seen reversals by governments who are all too readily persuaded that mining, tourism and other industrial activities matter more than preservation of our natural heritage. So protection is not just a matter of knowledge, it also demands continuing political will and political skills.

\section{ACKNOWLEDGEMENTS}

A broad-ranging review of this kind always owes a great debt to one's colleagues who are too numerous to name individually but they are valued and appreciated none the less. In this case, the author also expresses sincere thanks for the very thorough and critical review by the referees. Their efforts have contributed a great deal to the quality of the paper.

\section{REFERENCES}

Archer, M. (1978). Modern fauna and flora of the Texas Caves area, southeastern Queensland. Memoirs of the Queensland Museum 19: 111-119.

Australian Nature Conservation Agency (1996). A Directory of Important Wetlands in Australia (2nd Edition). Canberra: The Agency.

Bonyhardy, T. (1993). Places Worth Keeping. Allen and Unwin, Sydney.

Bozovic, M. (1997). Karst kao ekoloski fenomen. In Ljubojevic, V. (ed.), Simpozijum O Zastit Karsta: 7-16. Akademski Speleolosko-alpinisticki Klub, Belgrade.

Chapman, P. (1993). Caves and Cave Life. Harper Collins, London.

Churchill, S. (1998). Australian Bats. Reed New Holland, Sydney.

Clarke, A. (1997). Management Prescriptions for Tasmania's Cave Fauna. Hobart: Report to Tasmania RFA Environment and Heritage Technical Committee, Hobart.

Cox, G., James, J.M., Osborne, R.A.L. and Leggatt, K.E.A. (1989). Stromatolitic crayfish-like stalagmites. Proceedings University of Bristol Speleological Society 18: 339-358.

Danielopol, D.L. (1998). Conservation and protection of the biota of karst: assimilation of scientific ideas through artistic perception. Journal of Cave and Karst Studies 60: 67-58.

Downing, A. (1997). Bryophyes in Australian karstlands, In Sasowsky, I.D., Fong, D.W. and White, E.L. (eds), Conservation and Protection of the Biota of Karst: 14-16. Karst Waters Institute, Charles Town, WV. 
Downing, A. (1992). Distribution of bryophytes on limestones in Eastern Australia. The Bryologist 95(1): 5-14.

Downing, A. (1998). Changes in the assemblage of mosses on limestones in south-eastern Australia some implications for the management of karst systems. Australasian Cave and Karst Management Association Journal 30: 42-45.

Downing, A.J., Oldfield, R.J., and Selkirk, P.M. (1995). Bryopytes in the vicinity of Wombeyan Caves, New South Wales. Cunninghamia 4: 129-141.

Downing, A.J., Ramsay, H.P., and Schofield, W.B. (1991). Bryophytes in the vicinity of Jenolan Caves, New South Wales. Cunninghamia 2: 371-384.

Downing, A.J. and Selkirk, P.M. (1993). Bryophytes on the calcareous soils of Mungo National Park, An arid area of southern central Australia. Great Basin Naturalist 53: 13-23.

Downing, A.J., Selkirk, P.M. and Oldfield, R.J. (1997). The mosses of the Yarrangobilly Caves district, New South Wales, Australia. A review of the mosses collected by the Reverend W.W. Watts in 1906. Journal Hattori Botanical Laboratory 82: 105-121.

Duncan, A., Baker, G.B. and Montgomery, N. (eds). (1999). The Action Plan for Australian Bats. Environment Australia, Canberra.

Eberhard, R. (1994). Inventory and management of the Junee River Karst System, Tasmania. Forestry Tasmania, Hobart.

Eberhard, S. (1997). Impact of a limestone quarry on aquatic cave fauna at Ida Bay in Tasmania. Cave and Karst Management in Australasia 11: 125-137.

Eberhard, S. and Hamilton-Smith, E. (1998). Conservation of Cave Fauna in Australia, Cave and Karst Management in Australasia 12: 15-30.

Eberhard, S. and Hamilton-Smith, E. (2000). Conservation of cave communities in Australia, In Wilkens, H., Culver, D. C. and Humphreys, W. F. (eds.), Ecosystems of the World, vol. 30: Subterranean Ecosystems: 647-664. Elsevier, Amsterdam.

Eberhard, S. and Humphreys, W.F. (2000). The crawling, creeping and swimming life of caves, In Finlayson, B. and Hamilton-Smith, E. (eds.) Australia Underground. University of New South Wales Press, Sydney.

Eberhard, S.M., Richardson, A.M. and Swain, R. (1991). The invertebrate cave fauna of Tasmania. Report to the National Estate Office, Canberra.

Eberhard, S.M. and Spate, A. (1995). Cave invertebrate survey: toward an atlas of New South Wales cave fauna. 112 pp. Report prepared under the NSW heritage assistance program, National Parks and Wildlife Service, Queanbeyan.

Ford, D. and Williams, P. (1989). Karst Geomorphology and Hydrology. Unwin Hyman, London.

Gillieson, D.S. (1995). Rehabilitation of the Lune River Quarry, Tasmanian Wilderness World Heritage Area, Australia. Journal Australasian Cave and Karst Management Association 19: 4-10.

Gillieson, D. (1996). Caves: Processes, Development and Management. Blackwell Publishers, Oxford.

Godwin, M. (1983). Some Plants of the ChillagoeMungana area. Tower Karst, Chillagoe Caving club Occasional Paper 3: 46-70.
Hamilton-Smith, E. (1968). The insect fauna of Mt. Widderin Cave, Skipton, Victoria. Victorian Naturalist 85: 294-6.

Hamilton-Smith, E. (1970). Preliminary notes on the cavernicolous invertebrate fauna of the Mt Etna Caves, In Sprent, J.K. (ed.), Mount Etna Caves: 65-71. University of Queensland Speleological Society, Brisbane.

Hamilton-Smith, E. (1972). The bat population of the Naracoorte Caves area. Proceedings of the Eighth Biennial Conference, Australian Speleological Federation: 66-75. Australian Speleological Federation, Hobart.

Hamilton-Smith, E. (1991). The return of the bats. Nargun 23: 81.

Hamilton-Smith, E, Kiernan, K. and Spate, A. (1998). Karst Management Considerations for the Cape Range Karst Province of Western Australia. Western Australian Department of Environmental Protection, Perth.

Houshold, I. (1997). Karst impacts and environmental rehabilitation of a limestone quarry at Lune River, Southern Tasmania. Cave and Karst Management in Australasia 11: 138-175.

Howarth, F.G. (1983). Ecology of cave arthropods. Annual Review of Entomology 28: 365-89.

Howarth, F.G. and Stone, F.D. (1990). Elevated carbon dioxide levels in Bayliss Cave, Australia: implications for the evolution of obligate cave species. Pacific Science 44: 207-218.

Humphreys, W.F. (2000). The hypogean fauna of the Cape Range peninsula and Barrow Island, north-west Australia. In H. Wilkens, H., Culver, D.C. and Humphreys, W.F. (eds). Ecosystems of the World, vol. 30. Subterranean Ecosystems: 581-601. Elsevier, Amsterdam.

James, J.M. (1994a). Microbially produced carbon dioxide and studies on its effect on speleogenesis. In Sasowsky, I.D. and Palmer, M.V. (eds), Breakthroughs in karst geomicrobiology and redox geochemistry: 28-30. Karst Waters Institute, Charles Town, WV.

James, J.M. (1994b). Microorganisms in Australian caves and their influence on speleogenesis. In Sasowsky, I.D. and Palmer, M.V. (eds), Breakthroughs in karst geomicrobiology and redox geochemistry: 31-34. Karst Waters Institute, Charles Town, WV.

James, J.M., Patsalides, E., and Cox, G. (1994). Amino acids - a fingerprint for cyanobacteria in stromatolitic stalagmites. In Sasowsky, I.D. and Palmer, M.V. (eds.) Breakthroughs in karst geomicrobiology and redox geochemistry: 30-31. Karst Waters Institute, Charles Town, WV.

James, J.M. and Rogers, P. (1996). Evidence for a 'sulfureta' in Weebubbie Cave, Nullarbor Plain, Western Australia. In Hamilton-Smith, E. (ed.), Abstracts of papers, Karst Studies Seminar, Naracoorte: 11-12. Regolith Mapping, Hamilton.

Jennings, J.N. (1985). Karst Geomorphology. Basil Blackwell, Oxford.

Johnson, K. (1979). Control of Lampenflora at Waitomo Caves, New Zealand. Cave Management in Australia III: 105-122. South Australian National Parks and Wildlife Service, Adelaide and Australian Speleological Federation, Sydney. 
Juberthie, C. (1995). Underground Habitats and their Protection. Council of Europe, Strasbourg.

Juberthie, C. and Decu, V. (eds) (1994). Encyclopaedia Biospeologica, 1. Laboratoire souterrain du CNRS, Moulis, France.

Keighery, G. and Gibson, N. (1993). Biogeography and composition of the flora of the Cape Range peninsula, Western Australia. In Humphreys, W.F. (ed.), The Biogeography of Cape Range, Western Australia: 51-85. Records of the Western Australian Museum, Supplement No. 45.

Kiernan, K. (1995). An Atlas of Tasmanian Karst (2 vols.). Tasmanian Forest Research Council Inc., Hobart.

Lascu. C. (ed.) (1996). Piatra Altarului. Publisher not identified, Bucharest.

Lewis, J. (1996). The devastation and recovery of caves and karst affected by industrialization. In Rea, $\mathrm{T}$. (ed.), Proceedings of the 1995 National Cave Management Symposium: 214-227. Indiana Cave Conservancy Inc., Indianapolis, IN.

Lichon, M. (1993). Human impact on processes in karst terranes, with special reference to Tasmania. Cave Science 20: 55-60.

Macnamara, K. (1992). Stromatolites. Western Australian Museum, Perth.

National Speleological Society (1998). Selected abstracts from the 1998 National Speleological Society convention in Sewanee, Tennessee. Journal of Cave and Karst Studies 60: 179-192.

Neale, H. (1985). Management implications of research into Chironomid ecology. In Williams, D. and Wilde, K. (eds), Cave management in Australasia, VI: 59-76. Tourist Hotel Corporation of New Zealand, Waitomo.

Northup. D.E., A-L. Reysenbach, A-L and Pace, N.R. (1997). Microorganisms and Spelothems. In Hill, C and Forti, P., 1997. Cave Minerals of the World $\left(2^{\text {nd }}\right.$ Edition): 261-66. National Speleological Society, Huntsville, AL.

Northup D.E., Lavoie, K. and Mallory, L. (1997). Microbes in Caves. National Speleological Society News, 55: 111. (See also in http://www.caves.org/section/ ccms/lechnss!.htm)

Pecotich, L. (1980). A comment on the distribution and behaviour of the Northern Grey Swiftlet, Aerodramus spodiopygius in Chillagoe Caves. Down Under 19: 58-60.

Pecotich, L. (1982). Speciation of the Grey Swiftlet, Aerodramus spodiopygius, in Australia. Tower Karst 4: 53-57.

Poulter, N. (1991). Cave rights for troglobites. Preceedings of the Eighteenth Biennial Conference, Australian Speleological Federation: 15-24. Australian Speleological Federation, Sydney.

Price, L. and Steiner, H. (1999). Periplaneta australasiae (Blattidae), a new record for Dark Cave, Batu Caves. Malayan Nature Journal 53: 341-344.

Sasowsky, I.D., Fong, D.W. and White, E.L. (eds.) (1997). Conservation and Protection of the Biota of Karst. Karst Waters Institute Inc., Charles Town WV

Simmons, J.H. and Lohrey, A.L. (1985). Waitomo stream catchment management control scheme. In Williams, D. and Wilde, K. (eds), Cave management in Australasia
VI: 49-58. Tourist Hotel Corporation of New Zealand, Waitomo.

Simpson, K. G. and Smith, G.T. (1964). Bat mandible from Mt. Widderin Cave, Skipton, Victoria. Victorian Naturalist 81: 78-79.

Sket, B. (1997). Biotic diversity of the Dinaric karst, particularly in Slovenia: history of its richness, destruction and protection. In Sasowsky, I.D., Fong, D.W. and White, E.L. (eds), Conservation and Protection of the Biota of Karst: 84-98. Karst Waters Institute, Charles Town, WV.

Slaney, D.P. and Weinstein, P. (1997). Conservation of cave fauna: more than just bats. Memoirs of the Museum of Victoria 56: 591-596.

Smith, G.B. and Shipp, E. (1978). A new species of cavedwelling Nicoletid silverfish (Thysanura: Insecta) from the Texas Caves, Queensland. Memoirs of the Queensland Museum 19: 121-123.

Smyth, D., Pecotich, L., and Roberts, J. (1980). Notes on the distribution and breeding biology of the Grey Swiftlet, Aerodramus spodiopygius. Sunbird 11: 1-20.

Solem, A. (1988). Maximum in the minimum: biogeography of land snails from the Ningbing Ranges and Jeremiah Hills, northeast Kimberley, Western Australia. Journal Malacological Society of Australia, 9: 59-113.

Spate, A. (1996). Phytokarst. Journal Australasian Cave and Karst Management Association Inc. 25: 28-29.

Spate, A. (1997). Phytokarst: Part 2. Journal Australasian Cave and Karst Management Association Inc. 26: 30-31.

Spate, A., Hamilton-Smith, E., Little, L. and Holland, E. (1998). Best practice and tourist cave engineering. Cave and Karst Management in Australasia XII: 97-109.

Stebbins, R. E. (1988). Conservation of European Bats. Christopher Helm, London.

Tercafs, R. (1992). The Protection of the subterranean environment. conservation principles and management tools. In Camacho, A.I. (ed.), The Natural History of Biospeleology: 481-522. Museo Nacional de Ciencias Naturales, Madrid.

Thurgate, M. (1995). Sinkholes, Springs, and Spring Lakes. South Australian Underwater Speleological Society, Adelaide.

Thurgate, M. and Gillieson, D. (1999). Land classification and karst management at Jenolan Caves, N.S.W., Australia. Cave Management in Australasia XIII: 105110.

Vermeulen, J.J. and Whitten, T. (1999). Biodiversity and cultural heritage in the management of limestone resources: Lessons from East Asia. Directions in Development Series, The World Bank, Washington, DC.

Watson, J., Hamilton-Smith, E., Gillieson, D. and Kiernan, K (eds.) (1997). Guidelines for Cave and Karst Protection. International Union for Conservation of Nature, Gland, Switzerland and Cambridge, UK.

Webb, L.J. and Tracy, J.G. (1970). A brief survey of the vine thicket flora of the Mt. Etna - Limestone Ridge area. In Sprent, J.K. (ed.), Mount Etna Caves: 80-82. University of Queensland Speleological Society, Brisbane.

Wilkens, H., Culver, D.C. and Humphreys, W.F. (eds) 
(2000). Ecosystems of the World, vol. 30. Subterranean Ecosystems. Elsevier, Amsterdam.

Woodruff, D.S. and Solem, A. (1990). Allozyme variation in the Australian Camaenid land snail Christolabrum primum: a prolegomenon for a molecular phylogeny of an extraordinary radiation in an isolated habitat. The Veliger 33 (2): 129-139.

Yuan D. (1988). On the karst environmental system. In
Yuan, D. (ed.), Proceedings of the International Association of Hydroloogy $21^{\text {st }}$ Congress 1: 30-46. Geological Publishing House, Beijing.

Yussof, Shaharin (1998). The natural and other histories of Batu Caves. Malaysian Nature Society, Kuala Lumpur.

Manuscript received 18 April 2000; accepted 16 October 2000. 